\title{
SYMBOLS AND ABBREVIATIONS
}

MS Istanbul \# IO77

MS London \#2808

MS Rabat \#10o/I

MS Rabat \#326

MS Tehran \#3990

MS Qarawiyyin \#I774 Kitāb al-'Ușūl fī al-Naḥw. N/A. Fez,

(...)

ff.

pl.

ar. Madrasa Qarawiyyin \# 1774

Kitāb al-'Ușūl fĩ al-Naḥw. Io77 A.H. Istanbul, Süleymaniye Library \# 1077

Kitāb al-'Ușūl fì al-Nahw. 65ı. A.H. London, British Museum \#2808

al-Mūjaz fì al-Naḥw. 536 A.H. Rabat, National Library of the Kingdom of Morocco \# IOo $/ \mathrm{q}$

Kitāb al-Khațt. 536 A.H. Rabat, National Library of the Kingdom of Morocco \# IOO/q

Kitāb al-‘Ușūl fĩ al-Nahw. 536 A.H. Rabat, National Library of the Kingdom of Morocco \# 326

Kitāb al-'Ușūl fī al-Naḥw. 6ro A.H. Tehran, Majlis \#3990

ellipted element

folio

plural

Arabic 
